${ }^{2}$ Heller L. Parenteral nutrition in obstetrics and gynaecology. In: Greep JM, Soeters PB, Wesdorp RIC, et al, eds. Current concepts in parenteral nutrition. The Hague: Nijhoff Medical Division, 1977:179-86.

${ }^{3}$ Di Costanzo J, Martin J, Cano N, Laffargue F, Noirclerc M. Total parenteral nutrition and pregnancy. In: Howard AN, Baird IMcL, eds. Recent advances in clinical nutrition. Vol I. London: John Libbey, 1981 : 133-5.

4 Main NH, Shenkin A, Black WP, Russell RI. Intravenous feeding to sustain pregnancy in patients with Crohn's disease. Br Med f $1981 ; \mathbf{2 8 3}$ 1221-2.

${ }^{5}$ Cox KL, Byrne WJ, Ament ME. Home total parenteral nutrition during pregnancy: a case report. $\mathcal{F} P E N$ 1981;5:246-9.

(Accepted 18 November 1982)

University Departments of Surgery and Medicine and Department of Obstetrics and Gynaecology, Hope Hospital, Salford M6 8HD J C TRESADERN, FRCS, surgical tutor

G F FALCONER, MRCOG, consultant obstetrician and gynaecologist

L A TURNBERG, MD, FRCP, professor of medicine

M H IRVING, MD, FRCS, professor of surgery

\section{Successful pregnancy in a renal transplant recipient taking cyclosporin A}

There have been several reported successful pregnancies in renal transplant recipients receiving conventional immunosuppressive agents. A recent multicentre trial, however, suggested that cyclosporin $A$ is more effective than conventional immunosuppression in these patients. ${ }^{1}$ We report the first case of a pregnancy in a renal transplant recipient taking cyclosporin $\mathrm{A}$ as the only immunosuppressive agent.

\section{Case report}

A 27 year old patient had a successful renal transplant operation in February 1981 when treated with cyclosporin A. Two previous transplant operations in 1977 and 1979 with conventional immunosuppression had failed. She conceived in November 1981 when receiving cyclosporin A $450 \mathrm{mg}$ daily, which was continued at the same dose throughout the pregnancy. She remained normotensive with no proteinuria. Concentrations of serum creatinine (mean $98.5+\mathrm{SD} 6.0 \mu \mathrm{mol} / \mathrm{l} ; 1.1 \pm \mathrm{SD} 0.1 \mathrm{mg} / 100 \mathrm{ml}$ ) and urea (mean $7 \cdot 8+\mathrm{SD} 1.5 \mathrm{mmol} / 1 ; 46.7-\mathrm{SD} 9.2 \mathrm{mg} / 100 \mathrm{ml}$ ) remained stable, and the white cell count (mean $7 \cdot 4 \pm$ SD $1.3 \times 10^{9} / 1$ ) and platelet count were within normal limits. Haemoglobin concentration varied between 9.6 and $12 \cdot 2 \mathrm{~g} / \mathrm{dl}$.

Serial ultrasound cephalometry confirmed satisfactory fetal growth, and regular antenatal fetal heart tracings were normal. A placental lactogen estimation at 33 weeks of gestation was $9.4 \mathrm{mg} / \mathrm{l}$, but serial 24 hour urinary oestriol estimations carried out from 32 weeks were persistently below normal limits. Labour was induced at 38 weeks of pregnancy and a healthy boy weighing $2980 \mathrm{~g}$ delivered vaginally. The fetal heart rate remained stable throughout labour, and the Apgar score at five minutes was 9 . The baby had a haemoglobin concentration of $15.9 \mathrm{~g} / \mathrm{dl}$ and a white cell count of $23 \cdot 4+19^{9} / 1$ and careful clinical examination showed no hirsutism or congenital abnormality. Bilirubin concentration did not rise above $155 \mu \mathrm{mol} / 1(9 \cdot 1 \mathrm{mg} / 100 \mathrm{ml})$ and aspartate transaminase activity was normal (56 IU/1). The patient was advised against breast feeding because of the possible transfer of cyclosporin $\mathrm{A}$ into the breast milk. Mother and baby were allowed home on the seventh postpartum day.

Cyclosporin A was not detected in specimens of liquor obtained at amniocentesis at 36 weeks and at amniotomy, but this was not surprising given the very low water solubility of the drug. The drug was present in the maternal and cord blood at delivery in concentrations of 86 and $54 \mu \mathrm{g} / \mathrm{l}$ respectively. Cyclosporin $\mathrm{A}$ was also detected in samples of breast milk obtained on days $2(101 \mu \mathrm{g} / \mathrm{l}), 3(109 \mu \mathrm{g} / \mathrm{l})$, and $4(263 \mu \mathrm{g} / \mathrm{l})$ post partum. Maternal blood samples were not taken simultaneously with the milk samples, however, so that we could not calculate the distribution ratio between blood and milk.

\section{Comment}

Reports indicate that women with a well functioning renal transplant have a reasonable chance of delivering a healthy infant. There is, however, a small risk of congenital abnormality and fetal adrenal suppression when the mother is taking steroids ${ }^{2}$ and azathioprine. ${ }^{3}$ The fungal peptide cyclosporin $A$ has a selective action against $T$ cells, particularly those concerned in allograft rejection, and reports on the use of the drug in clinical renal transplantation have confirmed its powerful immunosuppressive properties. ${ }^{4}$

Studies in animals have not shown any teratogenicity of cyclosporin $A$, and the results in our case confirm that although the drug crossed the placenta there was no evidence of immunosuppression or congenital abnormality in the baby.

Interestingly urinary oestriol concentrations were persistently low while other parameters of fetal wellbeing were satisfactory. This has been reported in other renal transplant recipients and was presumed to be due to fetal adrenal suppression caused by steroid administration to the mother. We found that oestriol concentrations in urine specimens of other pregnant women were not reduced when mixed with urine from patients taking cyclosporin $\mathrm{A}$, thus indicating that this drug does not interfere with urine oestriol determinations. The low urinary oestriol excretion in pregnant renal transplant recipients may therefore be due to a relatively lower glomerular filtration rate.

Studies in animals show that cyclosporin $\mathrm{A}$ is excreted in breast milk in a maximum amount of $2 \%$ of the maternal dose (M Lemaire, unpublished Sandoz internal document, 1982), and this was confirmed by the detection of appreciable quantities of the drug in the breast milk of our patient. We therefore suggest that mothers taking cyclosporin A should avoid breast feeding.

Our findings suggest that we can be reasonably optimistic about the outcome of pregnancy in patients with a well functioning renal transplant receiving cyclosporin $\mathrm{A}$, and because there is no evidence of teratogenicity cyclosporin A may be the drug of choice in renal transplant recipients contemplating pregnancy. We recommend that patients should avoid pregnancy for two years after transplantation because of the increased risk of graft rejection during this period, and by two years patients will have reached their lowest immunosuppressive maintenance doses.

${ }^{1}$ European multicentre trial. Cyclosporin $\mathrm{A}$ as sole immunosuppressive agent in recipients of kidney allografts from cadaver donors. Preliminary results of a European multicentre trial. Lancet 1982;ii:57-60.

2 Gethens JH, Rosenkrantz JG, Tunnock SM. Teratogenic effects of azathioprine. F Pediatr 1965;66:959-61.

${ }^{3}$ Bongiovanni AM, McPadden AJ. Steroids during pregnancy and possible fetal consequences. Fertil Steril 1960;11:181-6.

${ }^{4}$ Clane RYC, White DJG, Thiru S, et al. Cyclosporin A in patients receiving renal allografts from cadaver donors. Lancet 1978;ii:1323-7.

(Accepted 25 November 1982)

Department of Obstetrics and Gynaecology, St Mary's Hospital, Portsmouth PO3 6AD

G J LEWIS, MB, MRCOG, senior registrar

C A R LAMONT, MB, FRCOG, consultant obstetrician and gynaecologist

Wessex Regional Renal and Transplant Unit, St Mary's Hospital, Portsmouth PO3 6AD

H A LEE, BSC, FRCP, professor of renal medicine

M SLAPAK, MS, FRCS, consultant transplant surgeon

\section{Carbon monoxide poisoning in a former mining community}

Many accidental cases of carbon monoxide poisoning result from the incomplete combustion of household gas. ${ }^{1}$ We describe an unusual cause of carbon monoxide intoxication affecting several elderly neighbours in a former mining town.

\section{Case histories}

Case 1-A 72 year old woman complained of lassitude on the day before she was found by neighbours in a semiconscious state. Her condition rapidly improved in hospital, and subsequent analysis of her blood showed 35\% saturation of haemoglobin by carbon monoxide.

Case 2-A 64 year old woman, who lived in the neighbouring bungalow to the patient in case 1 , was admitted to hospital on the same day. Also found unconscious, she was pale with flaccid limbs and several skin vesicles at pressure sites. Cerebrospinal fluid was normal, but an electrocardiograph showed transient $\mathrm{T}$ wave inversion. Carboxyhaemoglobin concentration was $50 \%$. Signs of extrapyramidal rigidity developed, and she died of bronchopneumonia four months later. At necropsy ischaemic cerebral softening was particularly severe in the basal ganglia. 